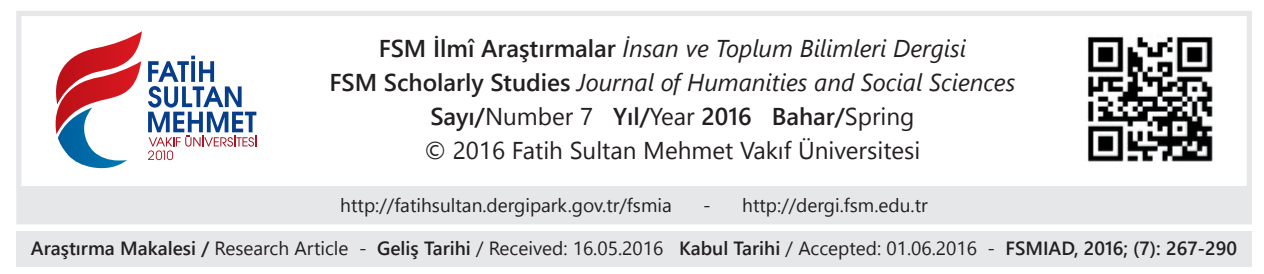

\title{
1905 Potemkin İsyanı ve Sultan II. Abdülhamid
} Hasip Saygılı*

\section{$\ddot{O} z$}

1905 yazı, Uzak Doğu'da Japonlar karşısında Rus ordusunun yenilgisini netleştirirken, Çarlık Rusyasında yılbaşında yeni bir aşamaya giren devrim hareketlerini de, yükseltmeye başlamıştır. Karadeniz'de isyan eden Potemkin zırhlısının oluşturduğu gerilim, Osmanlı ülkesinde tepeden tırnağa hissedilirken, Sultan Abdülhamid kuzey komşusunda çıkan krizi en az zararla atlatabilme ve bundan faydalanma yolları aramış ve bulmuştur.

Anahtar Kelimeler: Potemkin Zırhlısı, Sultan Abdülhamid, Çar Nikola, donanmada isyan.

\section{Potemkin Mutiny of 1905 and Sultan Abdulhamid II}

\section{Abstract}

As the defeat of Russian Army was getting clarified against the Japanese in the Far East in summer 1905, it also began to upgrade the revolutionary movement that drew into a new stage in the begining of the new year in Tsarist Russia. While the tension that The Battleship Potemkin generated rebelling in Black Sea, was perceived through and through in the Ottoman country, Sultan Abdulhamid II looked for a ways to overcome the crisis arisen in his northern neighbour with the least loss and benefit from it and came up with them.

Keywords: The Battleship Potemkin, Sultan Abdulhamid II, Tsar Nicolas II, naval mutiny.

* Doç. Dr., Fatih Sultan Mehmet Vakıf Üniversitesi Edebiyat Fakültesi Tarih Bölümü, İstanbul/ Türkiye, hsaygili@fsm.edu.tr 


\section{Giriş}

1917 yılında Bolşevik devrimi ile yıkılacak olan Rus Çarlığını sarsan dönüm noktalarından birisi 1905 devrimidir. 1905 yılında çarlık neredeyse çökecek hale gelmişti. Daha sonraları, 1917 Devrimi'nin kostümlü provası olarak görülecek olan 1905 Rus Devrimi'nin kayda değer olaylarından birisi de, Prens Potemkin Zırhlısı'nın isyanıdır. Potemkin İsyanı, ${ }^{1}$ Rusya'da Çarlığın devrilmesine yönelik askeri isyanlar içinde, en tanınmış olanıdır. ${ }^{2}$ Rusya'da Sovyet Dönemi'nin resmî görüşünü yansıtan Büyük Sovyet Ansiklopedisi'nin (Bolşaya Sovetskaya Entsiklopediya, 1969-1978), Potemkin İsyanı'nı anlatan maddesine göre başkaldırı, merkezî Rus Karadeniz Filosu'nun karargahı olan Sivastopol şehrinde bulunan Karadeniz Filosu Demokratik Örgütü Merkez Komitesi (Tentralka)'nin, 1905 sonbaharında filonun bütün gemilerinde eşzamanlı olarak çıkarmayı planladığı toplu isyandan önce, kendiliğinden ve olgunlaşmamış olarak ortaya çıkmıştır.

Donanmada devrimci bir isyanın zemini olarak, bahriyedeki şiddetli disiplin ve en küçük bir itaatsizliğin ağır bir şekilde cezalandırılması ve subaylarla neferler arasındaki düşmanlık gösterilmektedir. Bu zemini, devrimci kışkırtmalar olgun hale getirmiş olmalıdır. ${ }^{3}$

Kaynakların hemen hepsinin anlatımına göre Potemkin zırhlısı, 800'e yakın mürettebatıyla, ${ }^{4}$ atış ve manevra için 25 Haziran 1905 (eski takvime göre 12 Haziran 1905) günü Sivastopol'dan Tender adası civarına hareket etti. Ertesi gün

1 Devrimin lideri Lenin'e göre “Bunların en ünlüsü, Karadeniz'de isyancıların eline geçen ve Odesa'da devrime katılan Prens Potemkin zırhlısındaki ayaklanmadır. Devrimin yenilgisinden ve öteki limanları (örneğin Kırım>daki Feodosya limanını) ele geçirmeye yönelik başarısı girişimlerden sonra, zırhl, Konstanza'da Romanya makamlarına teslim oldu." V. I. Lenin, "1905 Devrimi Üzerine Konuşma", (yay. İ. Kaplan), 1977, http://www.urundergisi.com/makaleler. php?ID=1855, 24 Aralık 2011. Potemkin zırhlısının 11 gün süreyle isyanı, siyasî çerçevede önemli bir kilometre taşına işaret etmesi yanında film yapımcısı, şair ve ressamlara da ilham kaynağ1 da olmuştur. Bu çerçevede tanınmış Sovyet yönetmen Sergei Einstein'ın "Potemkin Zırhlısı" filmi, Boris Pasternak'ın "1905" adlı șiiri ile Francis Bacon'ın "Potemkin Zırhlısı" adlı tablosu hatıra ilk gelebilecek örneklerdir. Robert Zebroski, "The Battleship Potemkin and its Discontents, 1905-An International Perspective", Naval Mutinies of the Twentieth Century, by C. M. Bell and Bruce A. Elleman, Cornwall United Kingdom, Frank Cass Publishers, 2003, s. 9. Charlie Chaplin, Potemkin Zırhlısı'nın "dünyanın en iyi filmi” olduğunu savundu. Filmin çekiminden 33 yıl sonra, 1958 yılında 26 ülkeden yüzden fazla sinema tarihçisinin oluşturduğu jüri filmi "bütün zamanların en iyi filmi”" ilan etti. Ron Briley, "Sergei Eisenstein”, The History Teacher, (August 1966), 29/4, s. 528).

2 Alan Wood, The Origins of the Russian Revolution 1861-1917, (3 ed.), Routledge, 2003, s. 32.

3 Akdes Nimet Kurat, Rusya Tarihi-Başlangıçtan 1917'ye Kadar, Ankara, TTK, 1987, s. 383.

420 mürettebat subay, 4 mühendis subay, 2 doktor, 1 rahip, 12 astsubay ve uzman ve 763 denizci er. Bkz. Robert Zebroski, "The Battleship Potemkin and its Discontents, 1905-An International Perspective", Naval Mutinies of the Twentieth Century, by C. M. Bell and Bruce A. Elleman, Cornwall United Kingdom, Frank Cass Publishers, 2003, p.15. 
Potemkin'in refakatindeki 267 numaralı torpido botu, erzak almak için Odesa'ya ${ }^{5}$ gitti ${ }^{6}$. Odesa genel grevin ortasındayd. Grevci işçilerle, Kazaklar tarafından takviye edilen polis arasında çatışmalar olmaktaydı. Şehirde tedarikine ihtiyaç duyulan gida maddelerinin temini güçlük arzetmekteydi. Potemkin'in mübayaa astsubayı Makarov bir veya iki gün önce kesilmiş etlerden, 1008 pound (457 kg) kadar satın aldı. Satın alınan etler, torpido botu ile 6 saatlik bir seyirden sonra saat 16:00'da Potemkin'e getirildi. 27 Haziran 1905 sabahı saat 05:00'te, günlük faaliyetler için uyanan personelden bazıları, mutfaktan bozulmuş et kokusu geldiğini duyunca, dünkü alınan etlerin bozulmuş ve kurtlanmış olduğunu gördüler. Durum gemi komutanı Albay Golikov'a intikal ettirilir.

Potemkin'in komutanının emriyle, gemi tabibi Doktor Smirnov etleri muayene etti. Etteki kurtçukların tuzlu suyla yıkandığında, yemek için "mükemmel" olacağını bildirdi. Gemi komutanı Albay Golikov, mürettebatın görev yerlerine dönmelerini ve kurtlanmış eti görmeye gelen personelin isimlerinin alınmasını emretti. F Fakat denizciler arasında heyecan yatıșmad1:" "Şimdi böyle bir donanmada nasil hizmet ederiz? Japonya'da harp esirlerine dahi bizden daha iyi davranılırken, biz nasıl muharebe edebiliriz? " ve benzeri hoşnutsuzluk ifadeleri, mürettebat arasında yayıldı. Aslında Potemkin Zırhlısı personeli arasında, isyana eğilimli radikal denizcilerin sayısı yüzü geçmemekteydi. ${ }^{9}$ Radikal denizciler aralarında tartışıp öğle yemeği yememek şeklinde, pasif bir protestoda bulunmaya karar verirdiler. Öğleyin denizcilerden kimse yemeğe el sürmedi. İsyan, denizcilerin karınlarında başlamıştı. ${ }^{10}$ Potemkin mürettebatından hayatta kalan bir subay ile gece denize atlayıp sahile çıkan bir tayfanın ifadesine göre, olayların gelişimi aşağıdaki şekilde sürmüştür: ${ }^{11}$

“...Komutanın emriyle tayfa güverteye toplanmıs ve en büyük subay [gemi ikinci komutani] olan yarbay, yemeği reddetmeyen tayfaların, siralardan ayrılmaları emrini vermiştir. Tayfaların büyük kısmı sıralardan çıkmışlardır. Bunun üzerine kalan şikâyetçilerin isimleri kaydedilmeye başlanmıştır. Fakat bu kayıt sırasında askerler, çatılmış olan silahları yerlerinden kaparak doldurmaya başlamışlardır. Yarbay nöbetçilere, bu askerler üzerine ateş etmele-

5 Osmanlı arşiv belgelerinde ve basınındaki adı Hocabey.

6 A. Matushenko, "The Revolt on the Armoured Cruiser "Potemkin", (çevirimiçi) http://www. marxist.com/ History-old/ potemkin.html, 28 Şubat 2011, s. 2.

7 Robert Zebroski, Aynı makale, s. 15-16.

8 A. Matushenko, Ayn makale, s. 3.

9 Robert Zebroski, "The Battleship Potemkin and its Discontents, 1905-An International Perspective", s. 16.

10 Jonathan Sale, "Potemkin Mutiny, 27 June 1905", New Statesman, 21 June 1996, s. 13. Sale, 1996, s. 13.

11 İlhan Ekinci, «Potemkin Zırhlısı İsyanı ve Boğazlar Meselesi», Toplumsal Tarih, Nisan 2000, s. 42. 
rini emretmiş ise de emir yerine getirilmemiştir. Bunun üzerine yarbay tayfalardan birinin elinden tüfeğini alarak, asilerden birine iki üç el ateş etmiş ve öldürmüş̧ür. Bunu müteakiben tayfalar açıktan açığa isyan ederek, subaylar üzerine hep birden ateş etmeye başlamışlardır. Subaylar kaçıp saklanmak istemişlerse de, tayfalar takip ederek gemi komutanını ve birçok subayı öldürmüşlerdir. Tayfalardan da 30 kişi, yine asiler tarafindan katledilmiştir. Bunun üzerine diğer tayfalar ve Potemkin ile birlikte hareket edip üzerlerine top ve tüfekle ateş edilen torpido istimbotu mürettebatı da isyana katılmaya mecbur olmuşlardır."

Sonunda Potemkin'e kızıl bayrak çekildi. ${ }^{12}$ Sayıları yetmiş ile yüz arasındaki denizci, etkileri yıllarca sürecek bir isyan başlattılar. Gerçekte, ne Karadeniz Filo Komutanlığı, ne radikal politikacılar, ne de Karadeniz Filosu Demokratik Örgütü Merkez Komitesi Tsentralka, Potemkin mürettebatından bu kapsamda bir eylem beklememişti. ${ }^{13}$

İsyancılar, gemideki faaliyetleri yürütmek ve Potemkin başkaldırısının tüm Karadeniz Filosu'na yayılmasına kadar sürdürülmesini temin için, bir komite teşkil ettiler. ${ }^{14}$ Komite 20 kişiden oluşuyordu. ${ }^{15}$ Aynı gün 27 Haziran 1905 gecesi Potemkin, Odesa limanına geldi. Potemkin isyancı denizcilerin komitesi, isyan esnasında öldürülen tayfalardan Vakulenchuk'un cenazesini halkın katılımıyla defnetme, taze su ve kömür temini, Odesa'da yerel devrimcilerle temas kurma ve garnizondaki askerlerle Kazakların isyana katılması için çağrı yapılması kararı aldı. ${ }^{16} 28$ Haziran sabahı maktûl devrimci Vakulenchuk'un nâşı, Odesa'nın meşhur Richeliu basamaklarının eşiğine getirilir. Cenazenin göğsüne şu not iliştirildi: ${ }^{17}$ "Önünüzde, Potemkin zırhlisinda bozuk yemekten şikâyet ettiği için üst rütbeli bir subay tarafindan vahşice öldürülen, Gregori Vakulenchuk'un bedeni yatıyor. Haç çıkaralım ve 'ruhuna huzur' diyelim. İtikamımızı zalimlerden alalım. Zalimlere ölüm ve yaşasın özgürlük!"

Odesa'dan binlerce kişi, isyancı gemiyi görmek ve maktûl Vakulenchuk'un nâşına saygı göstermek rıhtıma indi. Zaten bir gün önce grevci işçiler, şehirde genel grev başlatmış polise ateşli silahlar ve taşlarla saldırmaya başlamışlardı.

12 Richard Cavendish, "The Mutiny on the Potemkin ", History Today, 55 (6), 14 June 2005, s. 54.

13 Robert Zebroski, "The Battleship Potemkin and its Discontents, 1905-An International Perspective", s. 18.

14 Robert Zebroski, Aynı makale, s. 18.

15 Captain Geoffrey Bennett, "The "Potemkin" Mutiny", Royal United Service Institution Journal, (104), November 1959, s. 417.

16 Robert Zebroski, Aynı makale, s. 18.

17 Hank Foglino, “The Potemkin Mutiny-Part I', (çevrimiçi) www.liboatingworld.com, February 2007, 10 Ocak 2012, s. 7. 
İsyancılara destek için toplanan bu kalabalık, öğleden sonra ambarları yağma ve limanın ahşap binalarını yakmaya başladı. Olaylar kontrolden çıktı. Ordu olayları bastırmak için, limanı kordon altına aldı ve kalabalığın üzerine ateş açtı ${ }^{18}$ Ertesi günün sabahına kadar 2000 kişi öldürüldü. Kurbanlar, asker kurşunu veya rıhtımda çıkarılan yangınlarla hayatlarını kaybetmişlerdi. ${ }^{19}$ Odesa limanı kısmen tahrip olmuş, 15 milyon rublelik maddi hasar meydana gelmişti. ${ }^{20}$

15 Temmuz 1905 (eski takvime göre 2 Temmuz 1905] tarihinde Çayd gazetesinde yayınlanan ve kuvvetle muhtemel, Sultan için Türkçe'ye tercüme edilen değerlendirmeye göre; ${ }^{21}$ Çar Nikola isyandan son derece müteessir olmuş, isyanın bastırılması için en şiddetli tedbirlerin alınmasını emretmiştir. Gazeteye göre Odesa'da meydana gelen isyan, Uzak Doğu'da Japonlar tarafından Rus Donanması'nın imhasından daha fazla "teessür" yaratmıştır.

Potemkin İsyanı komitesince, radikal unsurlar tarafindan 1srarla yapılan, Odesa'y1 ele geçirmek için şehrin topa tutulma teklifi üzerine, bu teklif kabul edilmemekle beraber, ${ }^{22}$ Odesa' da hükümet yetkililerine bir ültimatom verildi. İsyancılar eğer kendilerine karşı daha şiddetli tedbir alınırsa, şehri bombardımana tutacaklarını beyan ettiler. ${ }^{23}$ Hükümet yetkilileri, maktûl Vakulenchuk'un cenazesine isyancı denizcilerden bir heyetin katılmasını kabul etmelerine rağmen, isyancıların affedilmeyeceğini bildirdiler. ${ }^{24} 29$ Haziran tarihinde cenaze törenine katılan denizciler, gemiye dönerken üzerlerine askerler tarafından ateş açıldı, üç denizci hayatını kaybetti. Aynı gün akşamı, geçici garnizon karargâhı olan Odesa Tiyatrosu'na Potemkin'den üç top mermisi atıldı. Hedef sskalanınca, sivil halkın zarar görmemesi için ateş kesildi.

30 Haziran günü St. George [Georgi Pobedonets] ve diğer bazı harp gemilerinde de isyan çıktı. Ancak bu başkaldırılar, iki günden daha fazla sürmedi. İsyancı gemilerin teslim olmaları, Potemkin'deki isyan komitesinin morali bozdu. Bu şartlar altında 2 Temmuz 1905 tarihinde, Potemkin Romanya'nın Köstence limanına hareket etti. Aynı gün akşamı, refakatindeki istimbot ile Köstence limanına vardı. Potemkin, erzak ikmali ve hazırladıkları muhtıraların,

18 Sovyet yönetmen Sergei Eisenstein'in tanınmış filmi "Potemkin Zırhlısı”"nda askerlerin katliamından kaçan kalabalığın yüksek basamaklardan kaçışı etkileyici bir şekilde dramatize edilmiştir.

19 Robert Weinberg, "Workers, Pogroms, and the 1905 Revolution in Odessa", The Russian Review, 46, 1987, s. 58.

20 Robert Zebroski, Aynı makale, s. 19.

21 Başbakanlık Osmanlı Arşivi (BOA). Y. PRK. TKM. nr. 48-66, 1323 Ca 2.

22 Şehrin topa tutulma teklifinin kabul edilmemesinde Odesa'ya gelecek diğer harp gemilerinin de isyan edeceği beklentisinin olduğu iddia edilmiştir (Eder, 2007)

23 Robert Zebroski, Aynı makale, s. 19.

24 Igor Yeykeles, Potemkin Mutiny, In J. R. Miller, Encyclopedia of Russian History, New York, Macmillan Reference USA, 2004, s. 1214. 
Avrupalı devlet konsoloslarına verilmesini talep etti. 3 Temmuz sabahı erzak ikmali talepleri reddedilince, Potemkim zırhlısı, Kefe'ye dönmeye karar verdi. Kefe'de erzak ikmali ve isyan ateşinin kıvılcımını orada tutuşturmayı ümit ediyorlardı. 5 Temmuz'da Potemkin, Kefe limanına demir attı. Erzak ikmali sağlanması yanında, 6 Temmuz sabah saat 06:00'ya kadar içme suyu ve kömür verilmezse, şehrin topa tutulacağını bildirdi. Sürenin bitmesine rağmen Potemkin, şehri bombardımana tutmaya cesaret edemedi. Moral bozgunluğundaki Potemkin, 8 Temmuz 1905 tarihinde tekrar Köstence limanına giderek, Romanya makamlarına teslim oldu. ${ }^{25}$ Ancak bu, donanmada Çarlık için isyanların bittiği anlamina gelmeyecekti. ${ }^{26}$

Muhtemelen çevirisini Sultan Abdülhamid'in de okuduğu, Potemkin'in teslim olmasından sonra, Çayd gazetesinde yapılan bir değerlendirmede ${ }^{27}$ zahiren Çar'a saygı ifadeleri yanında, kışkırtıcı bir dille "ihtilâlin bu suretle hitam bulacă̆ asla memul değildi" denilerek, isyancıların hükümetin merhametine s1ğınmaktansa, zırhlı gemiyi batıracaklarının beklendiği ifade edilmiştir. Gazeteye göre, isyan eden mürettebat Japon olsaydı, durum farklı olacaktı. Başarısız isyancılar, gemiyi batırarak intihar ederlerdi.

\section{İsyanının İstanbul'da Yankıları ve Sultan Abdülhamid'in Girişimleri}

Potemkin zırhlısındaki isyan, doğal olarak İstanbul'da ilgiyle takip edilmiştir. İstanbul'daki Rus Büyükelçisi Zinoviyev, Petersburg'a yolladığ 12 Temmuz 1905 tarihli gizli raporunda, Rusya'da olan hiçbir olayın Potemkin zırhlısının isyanı kadar ilgi çekmediğini bildirmektedir. ${ }^{28}$

Sultan Abdülhamid'in Mabeyn Başkâtibi Tahsin Paşa da, olaylardan çeyrek asır kadar sonra kaleme aldığı anılarında, konuyu şu şekilde aktarmıştır:29

25 Robert Zebroski, Aynı makale, s. 21-23.

26 Potemkin İsyanı'ndan iki yıl sonra bile donanmada isyanlar devam etmişti. Petersburg sefaretinin 23 Mayıs 1907 tarihli raporuna göre "Amiral Çiyonskiınin tahtı kumandasında olup Tendir Körfezi'nde bulunan 'Sinop've 'Üç Aziz' nam zırhlılar nefaratı isyana tesaddi etmişlerdir. 25 Mayısta Bahriye Nezareti emri altında Tendir Sahili'ne çıkarak içtima etmişler buna ahali de iştirak ile bunu müteakip harekatı ihtilâlcuyâne başlamıştır. Müşevviklerin tasavvuru mürettebatı isyan ettirdikten sonra zabitanı denize attırarak telef etmek donanmayı zabt eylemek imis. Muharriklerin bu maksad-ı cinayesi umeray bahriyenin say ve tehdidat ve ittihaz olunan tedabiri müessire sayesinde semeresiz kalmış. İki zırhlı Sivastopol'a izam olunmuş ve 60 kişi tevkif olunmuştur" BOA. Y. PRK. EŞA. nr. 50-67, 1325 Ca 28. Robert Zebroski, Aynı makale, s. 21-23..

27 BOA. Y. PRK. TKM. nr. 48-66, 1323 Ca 2.

28 A. S., and V.N. Gudeva, Çernetsov, "Vliyanie Revolyutsii 1905-1907 gg. V Rossii Na Turtsiyu, İran i Kitay”, Novaya İ Noveyşaya İstoriya, (4), Temmuz-Ağustos 1976, s. 144.

29 Tahsin Paşa, Abdülhamit ve Yıldız Hatıraları, İstanbul, Muallim Ahmet Halit Kitaphanesi, 1931, s. 174. 
"Rusya'da zuhûra gelen tebeddüller ve isyanlar üzerine Rusya'nın Karadeniz Filosu'na mensup gemilerden Potemkin zırhlısı, limandan çıkarak Karadeniz'e açılmış, serseri bir surette bir hayli dolaştıktan sonra Boğaz'a yaklaşmişt. Bir sefine-i harbiye mürettebatının isyanı, Sultan Abdülhamid'in endişe ettiği mesaildendi. Asi bir geminin kendi tayfaları marifeti ile kaldırllip hod be-hod yola çıkarılması İstanbul'da şüyu bulursa, bunun bize de sirayet etmesi ve İstanbul askerlerinde de isyan hislerini uyandirmasl, ihtimali velev pek cüz'i dahi olsa, Sultan Abdülhamid'in uykusunu kaçırmaya kâfi idi. Rusya hükümeti, bu asi Potemkin zırhlısı üzerinde bir tesir icra edemiyordu. Zırhl Boğaz'a yaklaşmak üzere idi. Ya girmeğe teşebbüs ederse ne olacaktı?"

Aynı dönemde Sultan Abdülhamid'in Bahriye Müfettişi olan Komodor Bagnam'ın maiyetinde görev yapan Hüseyin Rauf [Orbay] Bey'in anlatımı da, Tahsin Paşa'nın yazdıklarını doğrulamaktadır: ${ }^{30}$ "Hükûmetimiz başta Saray olmak üzere, asilerin Boğaz'a taarruzları endişesiyle Karadeniz Boğaz'ını, ele geçirdikleri her vasita ile takviyeye çalıştılar. Bahriyemizde o gün elde harekete kadir, Haliç’te birkaç teşkilatımız vardı. Bunları Boğaz'a sevk ettiler."

Bir İngiliz kaynağa göre ise, Potemkin isyan edip Köstence’ye gelince, Türk Hükümeti alarma geçerek Boğaz girişini mayınlanmış ve zırhlının Boğaz’’ geçmeye teşebbüs etmesi halinde kıyı bataryalarınca ateş açılması emrini vermiştir. ${ }^{31}$ 4 Temmuz 1905 tarihli The Times gazetesine göre, Boğaz'da Türk Hükümeti, aldığ 1 güvenlik tedbirlerini iki katına çıkarmıştır. Bu çerçevede, Rus sefaretine ait Zaporezetz adlı gemi, içinde Büyükelçi Zinoviyev olduğu halde, akşam üzeri Karadeniz'den tenezzüh seyrinden dönerken manevra mermisi atılarak durdurulmuş, sabaha kadar gözetim altında tutulmuştur. ${ }^{32}$

Rusya'nın İstanbul Büyükelçisi Zinovyev, Potemkin zırhlısının Romanya makamlarına tesliminden hemen sonra, 12 Temmuz 1905 tarihinde Dışişleri Bakanlığı'na gönderdiği raporunda; Potemkin zırhlısının isyanı kadar Rusya' da son dönemdeki hiçbir olayın İstanbul'da ilgiyle takip edilmediğini yazmıştır. Büyükelçiye göre Sultan Abdülhamid, askerlerin darbesi sonucu tahtını ve hayatını kaybeden amcası Abdülaziz'in akibetini unutmayarak, derhal Osmanlı Donanması personeli arasındaki psikolojinin öğrenilmesi için ayrıntılı incelemeler yapılması talimatını vermiştir. Ayrıca Serasker Rıza Paşa, Tophane Müşiri Zeki Paşa ve Müşir Ethem Paşa'yı yanına çağırarak düşüncelerini almış, ${ }^{33}$ Potemkin zırhlısı Boğaz'1 geçmek isterse, önlenmesi için tedbirler alınmasını emretmiştir.

30 Cemal Kutay, Rauf Orbay 1881-1964 Hayat Hatıralart, İstanbul 1997, c. I, s. 259-260.

31 Captain Geoffrey Bennett, "The "Potemkin" Mutiny", Royal United Service Institution Journal, (November 1959) 104, s. 421.

32 "The Odessa Mutiny- Turkish Precautions", The Times, 4 July 1905, s. 5.

33 Konuya ilişkin Sadaret, Bahriye ve Tophane Feriklerine yazılan talimat taslağ için bkz. BOA. Y. PRK. ASK. nr. 231-13, 1323 Ca 04. 
Görüşlerine başvurulan generaller, Boğaz tahkimatlarının takviyesi lüzumuna işaret etmişler ve Boğaz istihkâmlarının takviyesi faaliyeti hemen başlatılmıştır. $\mathrm{Bu}$ çerçevede, eski topların yanına 12 inçlik yeni toplar konulmuştur. Bu topların mevzilendirilme faaliyetleri tamamlanmamış olsa da, Boğaz'ın Karadeniz tarafı mania mayınlarıyla kapatılmıştır. Büyükelçi, Osmanlı Devleti'nin Boğaz'da aldığ 1 tedbirlere ilişkin, kendisine Deniz Ataşesi tarafından etraflı malumat verilmekte olduğunu beyan ederek raporunu sonlandırmıştır. ${ }^{34}$ Raporun üzerinde, Çar Nikola tarafından 18 Temmuz 1905 tarihinde okunduğuna ilişkin bir not bulunduğuna göre; Rusya kendi içinde rejimi sarsan derin bir kriz yaşarken dahi, Boğazlarla ilgili gelişmelerden gözünü ayırmamaktadır.

İsyancı zırhlının Karadeniz'de bulunduğu dönemde, İstanbul'dan Petersburg sefaretine yazılan bir talimatta Sultan'ın Potemkin'den endişeleri sıralanırken; "Zırhlının dolaştı̆̆ Karadeniz sevahilinde müdafaasız limanlar da olup, gerçi müdafaasız limana kaideten taarruz edilmez ise de, mezkûr zırhlının korsan olması sebebiyle kavaide [göre] tatbik-i hareket etmeyeceği derkârdır." notu düşülmüştür. ${ }^{35}$ Korsan bir geminin ticaret gemilerine saldırması ihtimalinin de hesaba katılarak bu problemin bir an önce hal yoluna konulmak istendiği anlaşılmaktadır.

İlginç olan bir diğer husus ise, Sultan Abdülhamid'in Potemkin'de isyanın "birkaç mürettebat ve müşevvik-i fesad" tarafindan gerçekleştirildiği, mürettebatın ekseriyetinin bunlara içgüdüsel olarak uydukları değerlendirmesidir. Padişah'ın bu tahmininin şaşılacak derecede doğru olması dikkat çekicidir. Sultan Abdülhamid, Rus makamlarınca problemin şiddet kullanılmadan çözülmesinin telkini talimatını vermiştir. Bu kapsamda Potemkin'i takibe alan harp gemilerinin "sakinâne bir yolda davranmaları"nın maslahata muvafık olduğunu söyleyen Sultan Petersburgdaki sefirine Rus makamlarına münasip surette sonuç alıcı girişimlerde bulunmasını irade etmiştir.

Sultan Abdülhamid'in önerisinin, Rus makamlarınca nasıl karşılandığını şimdilik bilmiyoruz. Sultan'ın isyan bastırılamazsa batırılması emrini veren Çar Nikola'dan, ${ }^{36}$ daha soğukkanlı ve rasyonel değerlendirme yaptığı söylenebilir. ${ }^{37}$ Neticede Potemkin macerasının Sultan Abdülhamid'in tavsiyesi istikametinde sonuçlanması da ilginç bir gelişmedir.

Potemkin zırhlısının Köstence’ye gidişi, Hocabey Başşehbenderliği tarafından “..dün vakt-i zuhrda Dersaadet'e müteveccihen hareket eylediği” şeklinde

34 A. S., ve V. N. Gudeva, Çernetsov, "Vliyanie Revolyutsii 1905-1907 gg. V Rossii Na Turtsiyu, İran i Kitay”, Novaya İ Noveyşaya İstoriya (4), Jul-Aug. 1976, s. 144.

35 BOA. Y. PRK. EŞA. nr. 47-91, 1323 Ca 11. Başkitabetin 8 Temmuz 1905 tarihli yazısı.

36 Robert Zebroski, "The Battleship Potemkin and its Discontents, 1905-An International Perspective", s. 20.

37 Sultan Abdülhamid, muhazafakâr tarih yazıcılığında kendisini tahtından indirecek Hareket Ordusu'na karşı emrindeki Birnci Ordu'yu kullanmadığından dolayı eleştirilmektedir. 
rapor edilmiştir. ${ }^{38}$ Bu rapora dayanarak Ferik İsmail Hakk1 ve Serasker Rıza Paşa'ya “...malumat olmak ve ona göre tarassudat ve harekâtta bulunmak ve denize vaz edilecek torpidoların bu geceden ikmal-i tertibat ve ikâlna bezl-i mesai olmak üzere irade-i seniyye şeref-sadır" olduğu bilgisinin iletildiğini görüyoruz. ${ }^{39}$

O esnada Petersburg Sefareti, İstanbul'a yolladığı şifreli telgrafta, Rus hükümet yetkililerine dayanarak "Potemkin nam zırhlıdan dolay icra olunan teşebbüsat ve tebliğat üzerine, her nerede olursa olsun, buna pek yolunda bir nihayet verileceğ $i$ " haberini bildirmekteydi. ${ }^{40}$

Anılan tarihten bir gün sonra ise Köstence Başkonsolosluğu, zırhlının personelinin "Rusya'ya red ve iade edilmeyeceklerini zâmin" Romanya makamlarından bir senet aldıktan sonra, gemiyi teslim ettikleri bilgisini iletecekti. ${ }^{41}$ Potemkin'in zırhlısının Romanya makamlarına teslimi, 10 Temmuz 1905 tarihinde Sadrazam tarafindan Sultan Abdülhamid'e şu şekilde rapor edildi: ${ }^{42}$ "Kinyaz Potemkin nam Rus zırhlısının Köstence'ye ilk gelişinde, Romanya hükümetince teklif olunan şerait dairesinde, âhiren memurin-i mahalliyeye teslim olarak eslihası alınmış ve mürettebatı mülteci nazarıyla serbest bırakılmış olduğu ve dünkü gün Kral Şarl [Karol] Hazretlerinin emriyle memurin-i bahriye tarafindan, Rus Hükümeti tarafindan teslim alınmak üzere Sivastopol'dan gelen iki Rus zırhlısı ve dört torpidoya, sefinenin [Potemkin zırhlısının] teslim edildiği.."

Romanya makamlarına teslim olan Potemkin zırhlısı mürettebatının, mülteci olarak kabul edilmesine karşı Rusya hükümetinin hareket tarzı bilinmemekle beraber, Romanya konsolosunun ifadesine göre "iş olmuş bitmiş şeklini aldığından" Rusya'nın şiddetli itirazının pek de muhtemel olmadığı da padişaha verilen malumat arasındadır. ${ }^{43}$

Orman, Maadin ve Ziraat Nazırı, padişahın güvenilir adamlarından Selim Melhame Paşa ise Rusya büyükelçisi ile görüşmesi sonucunda Potemkin'in teslimini Sultan Abdülhamid'e şu şekilde rapor etmişti:44 “...Potemkin'in tayfaları arasında, yaptıklarından pişman olmuş olanlarla diğerleri arasında çıkan münaferetten, 30 kişi maktul olmuş olması nedeniyle, tayfalara dokunulmamak şartıyla, Romanya hükümetine teslim edilmesine karar vermişlerdir."

Büyükelçi nazır paşaya, Potemkin'e Köstence'de teslim olduğunda, Romen bayrağı çekilmesinin geçiçi olduğunu, zırhlı Rus makamlarına teslim edildiğinde

38 BOA. Y. PRK. BŞK. nr. 79-91, 1326 Z 29.

39 BOA. Y. PRK. EŞA. nr. 47-91, 1323 Ca 11. Başkitabet'in 9 Temmuz 1905 tarihli tezkeresi.

40 BOA. Y. PRK. BŞK. nr. 79-91, 1326 Z 29. Başkitabet'in 8 Temmuz 1905 tarihli tezkeresi.

41 BOA. Y. PRK. EŞA. nr. 47-91, 1323 Ca 11. Başkitabet'in 9 Temmuz 1905 tarihli tezkeresi.

42 BOA. YA. HUS. nr. 489-044, 1321 Haziran 27.

43 BOA. YA. HUS. nr. 489-044, 1321 Haziran 27.

44 BOA. Y. PRK. OMZ. nr. 3-54, 1323 Z 29. 
yine Rus bayrağının çekileceğini beyan etmişti. Selim Melhame Paşa'nın raporunda, tayfaların Potemkin'i terk ederken delikler açtıkları yönünde naklettiği söylentiyi, çağdaş kaynaklar da doğrulamaktadır. ${ }^{45}$ Romanya makamlarına teslim edilen Potemkin, daha sonra Rus makamlarına teslim edilerek Sivastopol'a götürülmüş̧ür. 14 Temmuz 1905 sabahı itibarıyla Sivastopol Başşehbenderliği İstanbul'a, zırhlının limana getirildiğini şifreli telgrafla bildirmiştir. ${ }^{46}$

Potemkin krizi döneminde Sultan Abdülhamid'in bir diğer ilgi çekici girişimi de İstanbul'daki yabancı sefaretler nezdindeki maiyet vapurlarını isyancı Rus zırhlısına karşı alınacak tedbirlere müdahil ettirme tasarısıdır. Hariciye Nazırı Tevfik Paşa'nın raporuna göre, Padişah'ın iradesi üzerine Potemkin Zırhlısının Boğaza gelmesi halinde "Hükümet-i Seniyye tarafindan icra kllınacak muamelatta, maiyet vapurlarının da hazır bulunmaları hakkında" büyükelçiliklere gereken bildirimlerde bulunulmuştur. ${ }^{47} \mathrm{Bu}$ gelişme üzerine Avusturya Büyükelçisi, Potemkin Zırhlısı İstanbul Boğazı'na geldiği takdirde gereken muamelenin Osmanlı Devleti'nce yapılmasına, kimsenin itiraz edemeyeceği gibi "sefaret maiyetinde böyle bir muamelata iştirak ve müdahaleye salih vapur bulunmadığını ve bu babda hükümet-i metbuasına müracaata dahi lüzûm olmadiğını" beyan etmiştir. Kezâ İngiltere Büyükelçiliği de, Potemkin'e karşı icra edilecek muamelenin Osmanlı Devleti'nin işi olduğu ve kendilerinin söz konusu girişime katılmalarının münasip olmayacağını bildirmiştir. Büyükelçilik esasen, maiyetinde bulunan küçük vapurun, topu dahi olmayan tenezzüh vapuru olduğunu beyan etmiştir. Ancak sıhhiye işlerinde kullanılacak istimbota, sefaret vapurları zabitlerinden birer kişi alınarak, muamelat mahallinde bulundurulmasının mümkün olduğunu, Baştercümanı vasıtasıyla tebliğ ettirmiştir.

Esasen Sultan Abdülhamid'in bu girişiminin, sorunu uluslararası bir hale sokarak karşılaşılan önemli sıkıntıyı savuşturma çabası olarak değerlendirmek mümkündür. Ancak İngiltere ve Avusturya gibi büyük devletlerin konuya yaklaşımları, Sultan'ın meşhur denge diplomasisinin bu olayda işlemesinin önüne geçmiştir.

Potemkin İsyanı, Osmanlı Devleti ile Rusya arasında Boğazlar konusunda kronik bir krizi tekrar gün yüzüne çıkarmıştır. Rusya, Osmanlı Devleti'nin Boğazları tahkim etmesini ve buralarda savunma tedbirleri almasını, Sultan Abdülhamid devri boyunca sürekli önlemeye çalışmıştır. Potemkin zırhlısının isyanı ile Sultan, inisiyatif alarak daha önce Rusya baskısı nedeniyle yapılamayan tahkimatların takviyesini sağlamıştır.

45 Robert Zebroski, "The Battleship Potemkin and its Discontents, 1905-An International Perspective", s. 23.

46 BOA. Y. PRK. ESSA. nr. 47-91, 1323 Ca 11

47 BOA. Y. PRK. EŞA. nr. 47-91, 1323 Ca 11. 
8 Temmuz 1905 tarihli ve İstanbul kaynaklı bir habere göre, Padişah Boğaz girişine iki gemi göndermiş ve Boğaziçi'ndeki tahkimatlara ağır toplar yerleştirmiştir. ${ }^{48}$ İki gün sonrasına ait yine İstanbul çıkışlı başka bir haberde, Rusya'nın baskılarına rağmen Bâbıâli, Karadeniz girişine ağır toplar yerleştirmeyi sürdürmektedir. ${ }^{49}$ Yazara göre Rus Karadeniz Filosu'ndaki son olaylar, tahkimat faaliyetleri için Türkler tarafindan bahane olarak kullanılmaktadır. ${ }^{50}$

Yukarıda yayınlanan haberden dört gün sonra, Rusya'nın İstanbul'daki sefiri Zinoviyev, Petersburg'a gönderdiği raporda Boğaz'ın savunması için, 120 milimetrelik topların mevzilendirildiği ve Boğaz girişine de mayın engellerinin yerleştirildiğini bildirmiştir. ${ }^{51}$

Başkâtip Tahsin Paşa'nın anılarına göre ise, tedbir olarak padişah, büyük topların Boğaz girişine mevzilendirilmesini emretmişti. Ayrıca Boğaz'a, savunma amaçlı istihkâmlar inşasına başlanmıştı. İstanbul'daki Rus Sefareti, bu istihkâm tesisinden memnuniyetsizliğini Babıâli'ye iletecektir. ${ }^{52} \mathrm{Bu}$ girişime cevap olarak isyancı Potemkin Zırhlısının Boğaza gelmesi halinde durdurulması ve İstanbul'u tehdit etmesine meydan vermemek gereken tedbirlerin alınması gerekliliği ifade edilmiş ve Boğaz istihkâmların tahkimi süratle tamamlanmıştı. ${ }^{53}$

Tahsin Paşa'nın işaret ettiği Boğazların tahkimatı faaliyetinin, Potemkin krizinin hallolunmasından sonra da devam ettiği anlaşılıyor. Tabii, Rusya'nın bu faaliyetten rahatsızlığını, diplomatik teamülleri zorlayarak Sultan Abdülhamid'e ilettiğini de, arşiv belgelerinden öğreniyoruz. 16 Eylül 1905 tarihli bir belgeye göre, Rusya'nın İstanbul Büyükelçisi, belge tarihinden bir gün önce Sultan'1 ziyaret ederek, "Meselenin Bahr-ı Siyah Boğazı istihkâmatının bu kere tahkim edilmekte olduğu keyfyetinin, hükümetince bir adem-i emniyet eseri addolunduğundan, Petersburg'da pek ziyade teessür hasil eylediğini ve bunun netayici, hükümeteyn beynindeki münasabata tesir eyleyeceğini" beyan etmiştir. ${ }^{54}$

Sultan Abdülhamid ise, alınan tedbirlerin "asla ve kat'a" Rusya hükümetine karşı olmadığını, sadece Bulgarların kötü niyet ve hareketleriyle, Romanya'nın

48 “Turkey's New Move", Ashburton Guardian, 10 July 1905, s. 2.

49 Başka bir gazete haberinde Boğaz çıkışındaki "Kavak”lara ağır topların mevzilendirildiği yazılmıştır. «Russia and Turkey”, Wangauni Herald, 20 July 1905, s. 5.

50 Taranaki Herald, 20 July 1905, s. 2.

51 A. S., and V.N. Gudeva, Çernetsov, "Vliyanie Revolyutsii 1905-1907 gg. V Rossii Na Turtsiyu, İran i Kitay”, Novaya İ Noveyşaya İstoriya, (4), Temmuz-Ağustos 1976, s. 144.

52 Sovyet tarih görüşü Çarlığın Osmanlı Devleti'nin savunma girişimlerinin tamamını devrimcilere karşı Çar ile Sultan'ın işbirliği olarak resmetme eğilimindedir. Bkz. V. İ Şpilkova, Mladotureçkaya Revolyuçsiya 1908-1909 gg., Moskova, İzdatelstvo "Nauka" Glavnaya Redakçiya Vostoçnoi Literaturi, 1977,s. 47-48. ve V. I. Lenin, "The Russian Tsar Seeks the Protection of the Turkish Sultan Against His People”, (BS. Isaac, \& I. Lasker, Editors), 1962, (çevirimiçi) http://www. marxists.org/archive/lenin/works/1905/jul/10bs.htm, 15 Ocak 2012.

54 BOA. Y. PRK. TŞF. nr. 7-102, 1323 B 16. 
Karadeniz'de bir donanma oluşturma çabalarına karşı, "tedabir-i ihtiyatkâriye yani payitaht-ı şahânelerinin kapısına, bir kilid vaz'ından ibaret olduğu, hatta Kal'a-i Sultaniye Boğazı'nda dahi aynı tahkimat icra olunmakta idiğünden ve bu da memleketin ve ahalinin emniyet ve selametini temin için, hükümetin bir vazifesi bulunduğundan, bunun bir su-i tefsire uğramaması matlûb-i hümayunları olduğunu" ifade etmiştir.

Rus Büyükelçisi ise Rusya'nın Bulgaristan ve Romanya'nın denizden İstanbul'u tehdit edeceklerine inanmadığını beyanla tahkimatı "mücerred kendisine karşı” bir güvensizlik eseri olarak algıladığını söylemiştir. Tahkimat faaliyetlerinin yanlış yorumlandığını tekraren ifade eden Sultan ise "bu babda her türlü teminatı ita eyleyeceğini" ifadeden sonra, Boğazlar'ın tahkim ve korunmasının uluslararası hukuka göre Osmanlı Devleti'nin meşru hakkı olduğunu, bu çerçevede Çanakkale Boğazı'nın da tahkimatının, yenilenme faaliyetlerinin de başladığından bahisle, "Bahr-ı Siyah Boğazı'na yalnız üç dört top gönderilmesinin ve bazı tamirat icrasinın, Rusya Devleti tarafindan su-i tefsir ile beraber adem-i emniyet addolunması, fevkalâde mucib-i teessü̈f" olduğunu ifade etmiştir.

Büyükelçi ise diplomatik teamülleri zorlayarak, “Karadeniz Boğazı'nın tahkimi ne suretle icra olunacağına malumatları bulunduğ $u^{55}$ ve vaz edilen topların mikdarl ise üç dört adetten ibaret olmadı̆̆ ve Karadeniz Donanması'nın adeta Karadeniz'de mahsur bir halde kalmış olduğunu” söylemiştir. Nihayet Padişah ise, Osmanlı Devleti'nin "muhibbi" olan Rusya gibi bir "devlet-i muazzamaya karşı kat' a" bir düşmanlık gösteremeyeceğini ve Büyükelçinin Petersburg hükümetini iknaya çalışmasını talep etmiştir.

18 Eylül 1905 tarihli Petersburg kaynaklı bir gazete haberi de, ${ }^{56}$ Rusya hükümetinin Türkiye'nin Boğaz tahkimatını güçlendirmeyi sürdürmesinden duyduğu "derin memnuniyetsizliği resmen" İstanbul'a bildirdiğini teyit etmektedir. Rus Dışişleri Bakanı Kont Lamsdorff'un, Boğaziçi tahkimatını yenilemesinin iki ülke arasındaki dostça ilişkilerle bağdaştırılamayacağını beyan ettiği de, aynı kaynak tarafından ileri sürülmüştür. Basına Ruslarca sızdırılan bu haberde, bahsi geçen "derin memnuniyetsizliğin" Türkiye'ye "resmen" bildirilmesi, yukarıda

55 Başkâtip Tahsin Paşa'nın anılarına göre de, “Rusya sefaretinin İstanbul belli başlı vazifelerinden biri Boğazların tahkimi keyfiyetini tarassut altında bulundurmaktı. Boğaza nazır bir mevkide ikamet eden Rus ateşenavalinin para ile kullandiğ casuslar vasitasile Boğazların ahvalinden mütemadiyen ve muntazaman haberler aldı ̆̆ kuvvetle muhtemel idi. Potemkin hâdisesini müteakip Boğaz'dan tahkim faaliyetinin başlaması ateşenavalın gözünden bittâbi gizli kalamazdı. Çok geçmeden Rusya sefareti Babıâliye müracat ederek Karadeniz boğazının tahkimine teşebbüs olunduğu haber alındığından ve bu tahkim münhasıran Rusyaya karşı bir şey olacağına nazaran iki devlet arasındaki dostlukta telifi kabil olamıyacağından bahisle serzenişte bulundu." Tahsin Paşa, Abdülhamit ve Yıldız Hatıraları, İstanbul 1931, s. 174.

56 "Fortifying the Bosphorus, A protest by Russia Regarded as Unfriendly Action", Thames Star, 20 September, s. 4. 
izah edilen Rus Büyükelçisi’nin Sultan Abdülhamid ile üç gün öncesindeki görüşmesinde olmalıdır.

$\mathrm{Bu}$ görüşme, Boğazların tahkimatının her iki tarafça ne anlama geldiğini de açık bir şekilde ortaya koymuştur. Sultan Abdülhamid, ülkesinin ekonomik, askerî ve sosyal yetersizliklerini göz ardı etmeden, muhtemel bir Rus tehdidine karşı başkentin Boğaz'dan güvenliğini güçlendirmeye çalışmakta, ancak bunu yaparken Rusları darıltmamaya çalışmaktadır. Kendisine karşı tedbir aldığı Çarlığın, Osmanlı Devleti’nin “muhibbi” olduğunu dahi ileri sürebilmiştir.

Çarlık ise, Abdülhamid'in Boğaz istihkâmlarını güçlendirme girişimlerini, bütün ayrıntılarıyla takip etmekte olduğunu itiraf etmiştir. Bu görüşmenin birkaç ay sonrasında Rusya'nın İstanbul Büyükelçisi ile görüsşen Padişah'ın sadık bendelerinden Selim Melhame Paşa'nın hazırladığı rapordaki “Boğaz'daki istihkâmların takviyesi hakkında lakırdı arasında, lisan-1 münasible ettiğim sözleri, sefir cevapsız geçmiştir.” İfadesi de ${ }^{57}$ her iki tarafın, 15 Eylül 1905 tarihli görüşmedeki bakış açılarını korudukları şeklinde anlaşılabilir.

Konu hakkında bir Rus akademisyen sunduğu bir tebliğde, ${ }^{58}$ "1905 yllında Padişah hükümeti, Petersburg'un hoşnutsuzluğunu gözardı ederek, İstanbul Bogazı'nın tahkiminde modernizasyona gitmiştir.” sonucuna varmıştır. Osmanlı Devleti'nin Boğazları tahkiminde, Rusya'nın Japonya ile yaptığı harpten mağlup olarak çıkması ve Rusya'nın 1905 Devrimi sarsıntıları ile meşgul olması, işini kolaylaştıran gelişmeler olmuş görünmektedir.

20 Kasım 1905 tarihli bir ajans haberinde ise Boğazlar'daki tahkimatın yenilenmesine öfkelenen Rusya'nın, Türkiye'den ödenmesi geçmiş 1877-1878 Savaşı'na ilişkin harp tazminatı taksitlerini ve faizlerini istediği, bu talebi karşılanmazsa Türk kıyılarında bir bölgeyi işgal edeceği bildirilmiştir. ${ }^{59}$ Bu haberin, Rusların daha sonra Karadeniz'den geçirmeyi tasarladıkları filonun geçişi için, Osmanlı Devleti üzerinde baskı kurma maksadıyla basına verildiği anlaşılmaktadır.

Potemkin İsyanı'nın sönmesinden sonra, muhtemelen Sultan'a da sunulan ve Berlin'de yayınlanan Lokal Anzeiger adlı bir Alman gazetesinin haber-yorumunun tercümesinde, ${ }^{60}$ "Potemkin sefinesi meselesi, Devlet-i Osmaniye Bahriye Nezaret 'ini derin uykudan uyandırmıştır" değerlendirmesi yapılmıştır. Gazeteye göre, 1897 Yunan savaşı ve Karadeniz'deki büyük Rus Donanması'nın varlığı, Osmanlı yetkililerini uyandırmazken, Potemkin İsyanı Karadeniz Rus Donanması'nın, İstanbul için ne kadar büyük bir tehdit oluşturduğunu göstermiştir. Gazete Boğazlar'dan Rus harp gemilerinin geçişine engel olabilmek için, ciddi tedbirle-

57 BOA. Y. PRK. OMZ. nr. 3-54, 1323 Z 29.

58 Ignatyev, B: XIX. Yüzyıl sonu ile XX. Yüzyıl Başında Türk Rus İlişkileri, Türk Rus İlişkilerinde 500 Y11 1491-1992 içinde, Ankara 1992, s. 156.

59 "Russia and Turkey", Marlborough Express, 21 November 1905, s. 2.

60 BOA. Y. PRK. TKM. nr. 48-67, 1323 Ca 18. 
rin alınmakta olduğunu yazmaktadır. İstanbul'dan alınan bilgilere göre, bu çerçevede Sultan; 2 zırhlı, 4 kravozör, 6 torpidotgeçer ve 12 torpil vapurunun [tedarik ve] inşasını emretmiş.. Ancak gazeteye göre, Osmanlı Devleti'nin içinde bulunduğu şartlar, bu projenin ileri bir zamana ertelenmesini gerektirecektir.

Jöntürk muhalefetinin keskin seslerinden, Kahire'de yayınlanan Türk gazetesinde olaylardan yaklaşı bir yıl sonra "Sultan bütün Türk bahriyesinin ıslahına karar vermiştir" şeklinde çıkan haber, ${ }^{61}$ donanmayı güçlendirme lüzumunun işareti olarak okunabilir.

Sadrazamın yukarıda işaret edilen raporunda ${ }^{62}$ Rusya sefareti baştercümanı Mösyö Maykof'un, Köstence'deki mürettebatın bir kısmının firar ederek, bir Hollanda vapuru ile İstanbul'a gelmek üzere oldukları beyanı hakkında; “...böyle bir şayia, mezkûr zırhlının teslimiyle mürettebatının serbest bırakıldiğı zamandan çok evvel işitilmiş olduğundan, rivayet ve ifadenin derece-i sihhati cay-i bahs görülmemekle beraber, Zabtiye Nezaret-i celilesine tebligat-ı lâzime icrası" teklifinde bulunmaktadır. Bu rapordan birkaç hafta sonra, Padişah yaverlerinden Ferik Şakir Paşa tarafindan hazırlanan bir raporda, ${ }^{63}$ Köstence'de Romanya Hükümeti'ne teslim olan Potemkin zırhlısı mürettebatından bir kısmının Romanya pasaportu ile İstanbul'a gelerek Beyoğlu, Büyükdere, Tarabya, Ayastefanos gibi ecnebilerle sâkin mahallerde takma isimlerle ikamet ettiklerinin istihbar edildiği bilgisi mevcuttur. Bunların arasında, "Nihilist ve anarşist komitelerine mensup eşhas-ı muzırranın mevcud bulunduğu şüphesiz bulunduğundan, bunların şu aralık Dersaadet'e men-i duhûlu veyahud ahval-i harekât-ı umumiyelerinin tarassudat-ı daime-i şedide altında bulundurulması için, memurin-i aidesine emr-i ferman buyrulması" teklif edilmiştir. Daha sonraki dönemde, Potemkin mürettebatından İstanbul'a birilerinin geldiğine dair herhangi bir bilgi ve iddia ile karşılaşılmadığından, bahse konu raporun padişahın bilinen vehim ve şüphelerini kışkırtarak, kişisel çıkar sağlamaya yönelik bir girişim olması muhtemel görünmektedir. Doğal olarak raporda, Rusya'daki devrimci harekete karışanlar için "nihilist" ve "anarşist" ifadeleri pejoratif anlamda kullanılmıştır.

Diğer taraftan Rusya, Potemkin'in tesliminden sonra Türkiye'ye bir nota vererek, kendilerine sığınabilecek isyancı zırhlının mürettebatına "adi suçlu” işlemi yapmasını talep etmiştir. ${ }^{64}$ Dönemin şartları gözönüne alınırsa, Osmanlı Devle-

61 "Havadis-i Dahiliye", Türk, 26 Kasım 1906, s. 2.

62 BOA. Y. A. HUS. nr. 489-044, 1321 Haziran 27.

63 BOA. Y. PRK. ASK. nr. 232-20, 1323 C 18.

64 "Accounts of Further Mutinies, Russia Wishes the Potemkin's Crew Recognised as Common Criminals", 5 July 1905, (çevirimiçi) http://paperspast.natlibs.govt.nz/cgi-bin/paperspast?a=$\mathrm{d} \& \mathrm{cl}=\quad$ search\&d$=W D T 19050705.2 .21 .4 \& \operatorname{srpos}=73 \& \mathrm{e}=01--1904---1908-100-1$-byTI--0Turkey+ Russia--, 13 Aralı 2011;"'The Potemkin Leaves Constanza”, The Times, 4 July 1905, s. 5. Miller, A. F: "Burjuaznaya Revolyuçiya 1908 g. v Turçii”, Sovetskoe Vostokvedenie (6), 1955, s. 35 . 
ti’ne sığınabilecek mürettebata, Rusya'nın talebi doğrultusunda işlem yapılacağı çıkarsanabilir.

\section{Jöntürk Muhalefetinin Gözüyle Potemkin ve Sultan Abdülhamid}

Potemkin İsyanı, dönemin istibdad rejimine karşı muhalefetini oluşturan Jöntürklerin gözüyle Abdullah Cevdet'in İçtihad mecmuasında, daha sonraki kaynaklarda ifade edilene benzer şekilde yansımıştır. Tabii isyanın nasıl çıktığı anlatılırken, maktulün bozuk yemekten şikâyet ettiği için anında komutanı tarafından tabanca ile vurulduğu gibi, daha sonra ortaya çıkacak olan ayrıntılarla çelişen ifadeler mevcuttur. ${ }^{65}$ Olayları yorumlarken Abdullah Cevdet'in kesinlikle Çar rejimine karşı isyancıların yanında olduğu açıktır. Ona göre, "derhal bütün efrad zalim kumandanın ceza-yı sezasını vererek leşini” yere sermiştir. Potemkin zırhlısının macerası anlatıldıktan sonra, hemen Abdülhamid idaresi ile ilintiler kurması da şaşırtıcı olmasa gerektir:

“...Potemkin vakasını bizim Abdülhamid-i Sâni işitince, hemen 'Ben donanmayı tahrip etmekte haklı değilmi imişim?' demiş. Bu yadigarların derece-i idrak ve faziletleri ancak bu kadardır. Potemkin isyan etti. Fakat insanca, adalet ve nesafet üzerine muamele görürken mi isyan etti. Tazallum-l hal eden [şartlardan şikâyet eden] bir tayfanın kafasını bir tabanca darbesiyle dağıtan bir kumandanin kemiklerini kırmak istemeyen ve öyle hazeleyi, kumandan zabit eden hükümete, buğz u nefret etmeyen hangi insan vardır? Abdülhamid'in sözünden pek aşikâr olarak anlaşlliyor ki, istediğini öldürtmek istediğini yaşatmak hak ve salahiyeti taraf-ı Rabbaniyeden [Tanrı tarafindan] hükümdarlara ve hükümdarların zabitan ve memurînine ihsan olunmuş zummunda bulunuyor."

Abdullah Cevdet, Sultan Abdülhamid'in Potemkin İsyanı'nı haber alınca, daha önce Yemen isyancılarını korkutmak üzere Cidde'ye gönderilmesini irade ettiği bir iki zırhlının hareketini iptal ettiğini yazıyor. İçtihad sahibine göre Potemkin vakası, Sultan üzerinde korku ve dehşet tesiri yaratmıştır. ${ }^{66}$

Jöntürk hareketinin kayda değer simalarından olan Abdullah Cevdet, Potemkin zırhlısı isyanının Çar otokrasisinin kötü idaresinden kaynaklandığını yazarken, Sultan'ın istibdadının da Osmanlı ülkesinde benzeri gelişmelere neden olabileceğini, satır aralarında ifade etmektedir.

Potemkin krizinin bastırılmasından bir ay kadar sonra, Şûra-yı Ümmet'te muhtemelen Ahmed Rıza Bey tarafından kaleme alınan bir yazıda, Çarlığın Sibirya'dan Karadeniz'e kadar büyük bir ihtilâlin karşısında olduğu ileri sürülmüş-

65 Abdullah Cevdet, "Rusya Ahvali”, İçtihad, (8), Temmuz 1905, s. 122-123.

66 Abdullah Cevdet, "Rusya Ahvali”, İçtihad, (8), Temmuz 1905, s. 123. 
tür. ${ }^{67}$ Yazıya göre Petersburg'da, Moskova'da, Varşova'da, Kronştad'da, Sivastopol'da, Odesa'da ihtilâl, başka bir tarza, başka bir şekle girmektedir. Evvelden şurada burada ayrı ayrı patlayan bombalar, şimdi toplara, evvelden erbab-1 zulüm ve istibdadı hedef eden revolverler, şimdi büyük harp silah ve araçlarına dönüşmeye başlamıştır. Devrim, münferit şahıslardan, toplumsal bir konuma yükselmiş görünmektedir. İntikam "Çarlığın" istibdadın, zulmün Rusya sosyal hayatında açtı̆̆1 ve insan yığınlarının düştüğü uçurumlardan, o uçurumların köşelerinden, mazlumların içlerinden yükselip çıkmaktadır: "[Potemkini zabt veya gark etmek isteyen Karadeniz Donanması zırhlılara Potemkin'in yanına bile yaklaşamamış. Çünkü] zabitlerin ceplerinde, Sivastopol'da müteşekkil bir cemiyet-i hürriyetin neşriyatı, efrad-ı bahriyenin ruhlarında bu neşriyatın asarı görüldü. Donanma, yalnız memleketleri tahrip eden toplarına değil, memleketleri ihya eden fikr-i hürriyetle de mücehhez imiş."

Şûra-yı Ümmet'in makalesine göre, Rusya Potemkin'in hareketini sanki mahalli bir isyan ve cinayet olarak göstermek istemiştir. Halbuki Potemkin'in neşrettiği "ilânname"ye göre her şey açıtır:

"Mazlum ve mağdur olan amele ve köylü kardeşlerimiz, fikir ve maksadınızı anlamayarak acaba belki hareketinizi katl ve sirkat ve bizler de şayan-ı nefret ve lanetle mi addediyorlar? Hayır biz milletin katil ve celladı değiliz. Onların fedakâr müdafileriyiz. İstediğimiz şey, memleketimizde sulh ve saadetin takriri! ...Mançuri muharebe-i eblehanesine hemen nihayet verilmesini talep ediyoruz. Bila-tehir ârâ-yı umumiyeye müstenid bir [genel oya dayalı] meclis-i mebusan teşkili konusunda musırrız [ısrarcıyız]".

Şûra-yı Ümmet yazarı da tıpkı Abdullah Cevdet gibi Potemkin zırhlısı isyanını istibdad rejimi ile ilişkilendirir ve bu hadisenin uzun yıllar süren Abdülhamid idaresinin devleti aciz ve düşkün bir hale düşürdüğünü ortaya çıkardığı iddiasında bulunur:

"Donanmadan ayrılarak kırmızı bir alem-i ihtilâl [kızıl devrim bayră̆ı] ile Karadeniz'de serseri dolaşmaya başlayan zırhll, evet bir zırhll, Devlet-i Aliyye'nin hayatını muhataraya ika eylesin! Koca bir saltanat, payitahtın topa tutulma korkusuyla sarsilsin! Demek ki Devlet-i Aliyye'nin cihan içindeki mevkii, Karadeniz'deki bu zırhliya mukavemet edemeyecek bir hale gelmiş. Devleti bu hale getirenler ve beka-yı şahsileri için beka-yı milleti bir zırhlının gasip [vicdanina] veya lütuf ve atıfetine terk edenler, hala o devletin, hala o milletin başında hükümdar olarak bulunuyor. Bunu bütün cihan içinde, bütün tarihi âlemde bu misal yoktur."

Yazar, Abdülaziz'i donanmaya önem verdiği için övdükten sonra, sözü Abdülhamid'in tahta çıkar çıkmaz memleketin savunma imkânlarını ve donanmayı 
mahvettiğine getiriyor: “Şimdi, Karadeniz'deki bu zırhlıya karşı titriyor. Tazarru ile istirham ile yerlere kapanıyor. Bahriye Nazırını Ereğli'ye göndererek, zırhl oralara gelirse her istediğini vermek, istediğini yapmak şartılla Boğaz içine girmemek için ${ }^{68}$ yalvarlyor. Devlet bu hale düşmüs, hayat-l millet, mevcudiyet-i vatan her türlü eshab-ı müdafaadan [savunma imkânlarından] mahrum edilmiş!"”

Şûra-yı Ümmet, Potemkin olayının devletin çok vahim durumda olduğunu gösterdiğinden dolayı, üst düzey devlet görevlilerini, Sultana karşı işbirliğine davet etmektedir:

"Her sinufta her meslekte her sanatta bulunan Osmanlılarin, tayin edecekleri mebuslarla bir yerde toplanmalıdır. Ordularımızın, askerlerimizin kumandanlarl zabitleriyle validelerini kurtarmak isteyen kardeşler gibi, ittihad edelim. Bir zırhlıya karşı, vatanın hakimiyeti tehlikeye girdiğini gören sadrazamlardan, vükeladan, ricalden, kumandanlardan, feriklerden, süferadan bir namus ve hakimiyet sahibi yok mudur? Birleşelim. musafahalar, ahd $\ddot{u}$ peymanlar edelim. Rusya'nın şu halinde vatanı, muhakkak olan mahv ve inkırazlardan kurtarınız." 69

Potemkin'deki ayaklanmadan iki ay kadar sonra yine yine Şûra-yı Ümmet'te yayınlanan bir yazıda da ${ }^{70}$ Abdülhamid'in kötü idaresi “... kesmekten, vurmaktan, hanümân yıkmaktan, kasten donanma batırmaktan vatanı bir hale getirdi ki, Karadeniz'de ihtilâl eden bir Rusya zırhlısl, koca bir Devlet-i Osmaniye'nin mevcudiyetini tehdit etti." şeklinde şiddetle tenkit edilmiştir. Muhtemelen Ahmed Rıza Bey'in kendi kaleminden çıkan bu yazıya göre, bütün felaketlerin, bu çerçevede Potemkin zırhlısının İstanbul'a geleceği söylentilerinin, başkentte doğurduğu telaşın da sorumlusu, Sultan'ın şahsıdır.

Potemkin İsyanı'ndan 21 yıl sonra İstanbul'da günlük bir gazetede, “1906 senesinde Türk Ordusunda Hürriyetperverler. Osmanlı Karadeniz Filosu zabitlerinden 28'i, Rusya 'daki hürriyet şehidini takdis etmişler! "Tarihî Ifşsat" başlı̆̆ 1 ile bir yazı yayınlanmıştır. ${ }^{71}$ Bu yazıya göre, Çarlık devrildikten sonra arşivlerde gizli polisten Hariciye Nazırlığına 21 Nisan 1906 tarihinde yazılan bir yazı ile Odesa'da Potemkin zırhlısı isyanının elebaşlarından idam edilen 11 kişi arasında, Peter Petroviç Şmidt adlı bir teğmenin ailesine, Osmanlı subaylarının destek

68 Aynı konu ile ilgili bkz. A. F Miller, "Burjuaznaya Revolyuçiya 1908 g. v Turçii”, Sovetskoe Vostokvedenie (6), 1955, s. 35. Şpilkova, V. İ: Mladotureçkaya Revolyuçsiya 1908-1909 gg., Moskova, İzdatelstvo "Nauka" Glavnaya Redakçiya Vostoçnoi Literaturi, 1977. s. 48. Sonuncu kaynak Ereğli’ye Potemkinin gelmesi ihtimaline karşı torpido botları da gönderildiğini yazmaktadır.

69 "Kinyaz Potemkin Zırhlısı», Şûra-yı Ümmet, (80), 16 Ağustos 1905, s. 2-3.

70 "Abdülhamid'e Atılan Bomba", Şûra-yı Ümmet, (80), 16 Ağustos 1905, s. 1-2.

71 "1906 senesinde Türk Ordusunda Hürriyetperverler.. Osmanlı Karadeniz Filosu Zabitlerinden 28'i Rusya'daki Hürriyet şehidini takdis etmişler!”, Milliyet, 22 Nisan 1926, s. 2. 
mesajı gönderdiği, bu mektubun Osmanlı Devleti sefaretine iletilmesi talep edilmiştir. ${ }^{72} \mathrm{Bu}$ yazının kaynağının, Krasniy Arxiv tarafından yayınlanan bir belge ${ }^{73}$ olduğu anlaşılmaktadır ${ }^{74}$. Gazete haberi ve kaynağı olan Rus resmi arşiv belgesinin orjinalliği, müstakil bir makalede eleştirilmiştir. ${ }^{75}$

72 Teğmen Şmidt'in Potemkin zırhlısı isyanı ile bir ilgisi yoktur. Potemkin İsyanı ile ilgili olarak sadece Matiuşenko adlı küçük rütbeli bir subay idam edilmiştir. O da 1907 y1lında ilan edilen aftan sonra dönmesinden sonradır. Robert Zebroski,"The Battleship Potemkin and its Discontents", Naval Mutinities of the Twentieth Century, An International Perspective, Ed. by Christopher M. Bell and Bruce A. Ellemen, 2003. Diğer taraftan Teğmen Şmidt'la beraber 11 kişinin idam edildiğinin dair iddiaya hiçbir dokümanda rast gelinmemiştir. Misal olarak Bkz. Robert Weinberg, "Workers, Pogroms, and the 1905 Revolution in Odessa", The Russian Review, vol. 46, 1987.

73 “Krasniy Arxiv vol. 2", (9). Leningrad-Moskova, 1925, s. 52-54.

74 Bkz., İ. M Reisner, "Russkaya Revolyutçiya 1905-1907 gg. i Probujdenie Azii”, Sovetskoe Vostokvedenie, (2), 1955, s. 14-30, s. 19. A. F Miller, "Mladotureçkaya Revolyuçiya", Pervaya Russkaya Revolyuçiya 1905-1907 gg. i Mejdunarodnoe Revolyuçionnoe Dvijenie, Moskova, Akademiya Nauk SSSR Otdelenie İstoriçeskih Nauk, 1956, c. 2, s. 326-327. H. Aliyev, "İz İstorii Burjuazno-Revolyuçionnogo Dvijeniya v Turçii” (Koneç XIX- Naçalo XX vv.). Türkiye Tarihi Meseleleri", Bakü, Azerbaycan SSR Elmler Akedemyası, 1972, s. 63.

75 Hasip Sayg111, "The Condolence Message of the Ottoman Black Sea Fleet in 1906: Critique of a Russian Red Archive Document”, Gazi Akademik Bakış, Kış 2012, s. 11, s. 165-175. 


\section{Sonuç}

Potemkin zırhlısının isyanı, İstanbul'da Sultan Abdülhamid tarafindan çok yakından takip edilmiştir. Zırhlının Odesa limanından ayrılmasının, İstanbul'a geleceği şeklinde rapor edilmesi üzerine, hemen o gece tedbir alınması için ilgili makamlara emirler verilmiştir. ${ }^{76}$ Boğaz'a mayın döşenmiş, Potemkin geçmeye teşebbüs ederse, istihkâmlardan top atışı ile mani olunması için, hazırlıklar yaptırılmıştır. Tabyalara, Tophane depolarından büyük çaplı güçlü toplar mevzilendirilmiştir. Hatta bir Rus akademisyene göre, tabyalardan gece geçen her türlü deniz taşııtına ateş açma emri verilmiştir. ${ }^{77}$

Kriz firsatından yararlanılarak, Boğaz'ın istihkâm vasıtaları güçlendirilmiştir. Dönemin yabancı basınına göre Rusya, daha önceleri bu tarz tedbirlere, kendisine karşı güvensizlik olarak gördüğü için engel olurdu. ${ }^{78}$ Boğazlar'daki tahkimatın güçlendirildiği haberini veren başka bir gazete, ${ }^{79}$ Bâbıâli'nin Karadeniz Filosu'nun ayaklanmasını firsata çevirerek, tahkimatını takviye ettiğini yazmıştır. Bu faaliyetler icra edilirken, Rusya'yı gücendirmeyecek diplomatik bir dil kullanılması tercih edilmiştir.

Potemkin krizinde Sultan Abdülhamid, Batılı devletleri de işin içine katarak, devletin ekonomik ve askerî yetersizliklerini dengelemek istemiştir. Ancak Avusturya ve İngiltere bu girişimde, Potemkin zırhlısının Boğaz'a gelmesi halinde "sefaret maiyet vapurlarını" da Osmanlı Bahriyesi ile beraber bulunma teklifine, sıcak bakmamışlardır. Arşiv belgelerine göre, diğer devletlerden de olumlu cevap alınamamıştır.

Diğer taraftan Potemkin hadisesi, Osmanlı Devleti'nin yetkin bir donanma ihtiyacını da ortaya çıkarmıştır. Sultan Abdülhamid'in donanmayı güçlendirme tasavurlarının, ekonomik güçlüklerden dolayı gerçekleştirilemediği anlaşılmaktadır. Donanmayı güçlendirme için, Sultan'ın mutlak iktidarını yitirdiği 23 Temmuz 1908 devriminden sonra, çeşitli yardım kampanyaları ile bazı deniz harp vasitaları temin edilebilecektir.

Dönemin konu hakkındaki Osmanlı arşiv belgeleri, rejimin isyancı Potemkin zırhlısının, devletin güvenliğini zedelemesinden endişe ettiğinini göstermektedir. Padişah, Potemkin' in "korsan" bir gemi olarak yerleşik denizcilik hukuku kurallarını tanımayacağından, Karadeniz sahillerindeki savunmasız limanlara sald1rabileceği, Karadeniz'deki ticaret gemilerine tecavüzle denizde ticari seyrüsefer faaliyetlerini durduracağı gibi risklerden söz etmektedir. ${ }^{80}$

76 İlhan Ekinci, «Potemkin Zırhlısı İsyanı ve Boğazlar Meselesi», Toplumsal Tarih, Nisan 2000, s. 45.

77 V. İ Şpilkova, Mladotureçkaya Revolyuçsiya 1908-1909 gg., Moskova, İzdatelstvo "Nauka" Glavnaya Redakçiya Vostoçnoi Literaturi, 1977. Şpilkova V. İ., 1977, s. 48.

78 “Turkey's New Move", Ashburton Guardian, 10 July 1905, s. 2.

79 "Russia and Turkey, Fortifications on the Bosphorus", Taraniki Herald, 19 September 1905, s. 2.

80 BOA. Y. PRK. EŞA. nr. 47-91, 1323 Ca 11. 
Çar Nikola’nın üzerine, “dikkate alınmasın” notunu yazdığı, Rusya'nın İstanbul Büyükelçisinin raporunda işaret ettiği ${ }^{81}$ Potemkin İsyanı ile Sultan'ın, kendi donanması personelinin ne yönde olduğuna ilişkin araştırmalar yaptırması gibi "içeriye" yönelik tedbir izlerine, ulaşabildiğimiz Osmanlı resmî evrakında, rast gelinmemiştir. Ancak Sultan'ın vehimli kişiliği ve müdahil veya tanık olduğu komplolar gözönüne alınırsa, Büyükelçi Zinoviyev'in iddialarının yadsımak kolay görünmemektedir.

Bu çerçevede bir kısım ricalin, hükümdarın kuşkularını kışkırtma maksadıyla Potemkin personelinin İstanbul'a gelmiş oldukları yönünde raporlar vermiş olmalar1, ${ }^{82}$ dikkat çekicidir. Ancak ilgili evrak dosyalarında Sultan'ın, bu tarz "arîzalara" işlem yapılması yönünde bir iradesine rast gelinmemiştir. Jöntürk muhalefeti ise Potemkin İsyanı'nı, çürüyen Abdülhamid rejimi ile Çarlık otokrasisi arasında paralellikler kurmak için, bir fırsat olarak karşılamış görünmektedir.

Bazı akademisyenlerce, resmi bir Rus belgesine dayanılarak, ${ }^{83}$ Potemkin İsyanı'ndan 9 ay sonra idam edilen Teğmen Şmidt'in ailesine, Osmanlı Karadeniz Donanması'ndan 28 subayın taziye mektubu yazması, sorgulanmamış bir veri olarak kabul edilmiş, bu "mektubun", "Türk kara ve deniz subayları arasında" Rus ihtilâlinin oluşturduğu güçlü bir yankı olduğu ileri sürülmüş̧ür. ${ }^{84}$ Ancak "sorunlu” Rus arşiv belgesi dışında, Potemkin İsyanı'nın Osmanlı subay ve neferleri arasında Abdülhamid rejimine karşı eyleme geçmek için, bir motivasyon yaratt1ğına ilişkin bir emareye rast gelinmemiştir.

Potemkin krizi ve sonrası, Rusya'nın Osmanlı Devleti ile ilişkileri açısından değerlendirildiğinde ise, Rusya'nın Boğazlar üzerindeki değişmeyen emellerini, ${ }^{85}$ asla unutmadığ görülmektedir. Boğaz'daki tahkimatın sefaret ve haber elemanları vasıtasıyla ayrıntılarıyla takip edilmesi, ${ }^{86}$ hatta bizzat büyükelçinin ağzından Sultan Abdülhamid'e, Boğaz'da yapılan faaliyetlerin ayrıntılarını bildiklerinin beyanı ${ }^{87}$ bu kapsamda zikrolunabilir. Olaydan yarım yüzyıl sonra, bir

81 Çernetsov, A. S., and V.N. Gudeva,: "Vliyanie Revolyutsii 1905-1907 gg. V Rossii Na Turtsiyu, İran i Kitay", Novaya İ Noveyşaya İstoriya, (4), Temmuz-Ağustos 1976, s. 141-150.

82 BOA. Y. PRK. ASK. nr. 232-20, 1323 C 18.

83 "Krasniy Arxiv vol. 2", (9). Leningrad-Moskova, 1925, s. 52-54.

84 Ivar Spector, The First Russian Revolution-Its Impact on Asia, New Jersey, Printice-Hall Inc, 1962. Spector, 1962, s. 66.

85 Akdes Nimet Kurat, Türkiye ve Rusya, Ankara 1990, s. VIII-IX, 92-138. Khostov, BS.: "Proekt zahvata Bosfora v 1896 g..”, 2008(1933), (çevirimiçi) http://www.vostlit.info/Texts/Dokumenty/ Turk/XIX/1880-1900/Zachvat_Bosfora_1896/text.htm, 24 Nisan 2011. Khostov, BS.: "Çarskoe pravitelstvo o probleme prolivov v 1898-1911 gg.", 2008(1933), (çevirimiçi) http:// www. vostlit.info/Texts/ Dokumenty /Turk/XIX/1880-1900/Probema_prolivov/text.htm, 24 Nisan 2011.

86 Tahsin Paşa, Abdülhamit ve Yıldız Hatıraları, s. 174.

87 BOA. Y. PRK. TŞF. nr. 7-102, 1323 B 16. 
Rus akademisyenin gözüyle bu durum açık bir şekilde ifade edilmiştir:88 "Böylece mevcut şartlar altında Rusya, Osmanlı kontrolü altında bulunan Boğazlar'daki ekonomik ve stratejik menfaatlerini korumak ve sonra da kendisini burasinın sahibi olmaktan alıkoyacak her türlü gelişmeyi önliyecek tedbirleri almalıydl."

Diğer taraftan Potemkin İsyanı nedeniyle zor durumda kalan Çarlık, bizzat devrimin tartışılmaz önderi Lenin tarafından, Türk Sultan'ın yardım talebinde bulunmakla ağır bir şekilde eleştirilmiştir. ${ }^{89}$ Lenin'e göre Rus ordusuna güvenemeyen Çar, Sultan Abdülhamid gibi yabancı güçlere yalvarmaktadır. Sultan da, Çarın talebini seve seve kabul etmiştir.

1905 yazında üst üste yaşanan Rus-Japon Savaşı'nın neden olduğu gerilimler, Potemkin krizi ve kendisine karşı Ermeni teröristler tarafından düzenlenen bombalı saldırı, 28 yıldır ülkeyi tek adam olarak idare eden Sultan Abdülhamid'in sinirlerini daha da yıpratmış olmalıdır. İstibdadla adı özdeşleşen hükümdarın, hemen her şeyden kuşkulanan vehimli ruh halinin, bu son olay üzerine iyice kışkırtılmış olduğu çıkarsanabilir.

Yine 1908'de, Padişah'ın mukavemet etmeden Meşrutiyet'i ilan etmesinde ve 31 Mart Olayı üzerine İstanbul'a giren Hareket Ordusu'nun kendisini tahtından edebileceğini kestirebilecek yetenekte olduğu bilinmesine rağmen, emrindeki Birinci Ordu'yu kullanmamasında da, 1905 yazında yaşadığı travmatik olayın ağırlığının olması düşünülebilir.

88 Bolsover, G. H: “1815-1914 Arasında Rus Dış Politikasına Bir Bakış”, Belleten, (Nisan 1966,) XXX, 118, s. 265-290. Bolsover, 1966, s. 281.

89 V. I Lenin, "The Russian Tsar Seeks the Protection of the Turkish Sultan Against His People", (BS. Isaac, \& I. Lasker, Editors), 1962, (çevirimiçi) http://www. marxists.org/archive/lenin/ works/1905/jul /10bs.htm, 15 Ocak 2012. Jöntürk muhalefeti de Sultan Abdülhamid'i halka karşı Rus Çarı'nı yardıma çağırmakla sürekli itham etmişlerdir. Bu iddianın kaynağı dönemin tanınmış Türk aydını Halil Halid Bey'in de aktardığı Sultan'ın Avrupa devletlerinin Osman11 içişlerine müdahaleye devam ederlerse Rusya'yı yardıma çağıracağı yönündeki "demarşı" olmalıdır. Halil Halid, "A Pacifik Revolution in Turkey”, The Orient Review, January 1908, (Vol:1), 1, s. 18-28. 


\section{Kaynakça}

\section{Başbakanlık Osmanlı Arşivi (BOA) evrakı dipnotlarda gösterilmiştir.}

"1906 senesinde Türk Ordusunda Hürriyetperverler.. Osmanlı Karadeniz Filosu Zabitlerinden 28'i Rusya'daki Hürriyet şehidini takdis etmişler!”, Milliyet, 22 Nisan 1926.

Abdullah Cevdet, "Rusya Ahvali”, İçtihad, (8), Temmuz 1905.

“Abdülhamid'e Atılan Bomba”, Şûra-yı Ümmet, (80), 16 Ağustos 1905.

"Accounts of Further Mutinies, Russia Wishes the Potemkin's Crew Recognised as Common Criminals", 5 July 1905, (çevirimiçi) http://paperspast.natlibs.govt.nz/cgi-bin/paperspast? $\mathrm{a}=\mathrm{d} \& \mathrm{cl}=$ search $\& \mathrm{~d}=\mathrm{WDT} 19050705.2 .21 .4 \& \mathrm{~s}-$ rpos=73\&e= 01--1904---1908--100--1 -byTI---0Turkey+ Russia--, 13 Aral1k 2011.

Aliyev, H., "İz İstorii Burjuazno-Revolyuçionnogo Dvijeniya v Turçii (Koneç XIX- Naçalo XX vv.) Türkiye Tarihi Meseleleri”, Azerbaycan SSR Elmler Akedemyası, Bakü, 1972.

Bolsover, G. H., "1815-1914 Arasında Rus Dış Politikasına Bir Bakış”, Belleten, XXX, 118, Nisan 1966.

Cavendish, Richard, "The Mutiny on the Potemkin “, History Today, 55 (6), 14 June 2005.

Ekinci, İlhan, "Potemkin Zırhlısı İsyanı ve Boğazlar Meselesi», Toplumsal Tarih, Nisan 2000.

Foglino, Hank, "The Potemkin Mutiny-Part I", (çevrimiçi) www.liBOAtingworld.com, February 2007.

"Fortifying the Bosphorus, A protest by Russia Regarded as Unfriendly Action", Thames Star, 20 September 1905.

Geoffrey Bennett, Geoffrey, "The "Potemkin" Mutiny", Royal United Service Institution Journal, (104), November 1959.

Gudeva - Çernetsov, "Vliyanie Revolyutsii 1905-1907 gg. V Rossii Na Turtsiyu, İran i Kitay”, Novaya İ Noveyşaya İstoriya, (4), July August 1976.

Halil Halid, "A Pacifik Revolution in Turkey", The Orient Review, vol. 1 (1), January 1908.

“Havadis-i Dahiliye”, Türk, 26 Kasım 1906.

Ignatyev, B., "XIX. Yüzyıl sonu ile XX. Yüzyıl Başında Türk Rus İlişkileri”, Türk Rus İlişkilerinde 500 Yıl 1491-1992 İçinde, Ankara, 1992. 
Khostov, BS., "Çarskoe pravitelstvo o probleme prolivov v 1898-1911 gg.", 2008 (1933), (çevrimiçi) http://www. vostlit.info/Texts/ Dokumenty /Turk/ XIX/1880-1900/Probema prolivov/text.htm, 24 Nisan 2011.

, "Proekt zahvata Bosfora v 1896 g..”, 2008(1933), (çevrimiçi) http://www.vostlit.info/Texts/Dokumenty/ Turk/XIX/1880-1900/Zachvat_Bosfora 1896/text.htm, 24 Nisan 2011.

“Kinyaz Potemkin Zırhlısı», Şûra-yı Ümmet, (80), 16 Ağustos 1905.

Krasnly Arxiv, vol. 2 (9), Leningrad-Moskova, 1925.

Kurat, Akdes Nimet Kurat, Türkiye ve Rusya, Ankara, Kültür Bakanlığı, 1990. „Rusya Tarihi -Başlangıçtan 1917’ye Kadar, Ankara, TTK, 1987.

Kutay, Cemal, Rauf Orbay 1881-1964 Hayat Hatıraları, c. I, İstanbul, 1997.

Lenin, “1905 Devrimi Üzerine Konuşma”, yay. haz. İ. Kaplan, 1977, http:// www.urundergisi.com/makaleler.php?ID=1855, 24 Aralık 2011.

, "The Russian Tsar Seeks the Protection of the Turkish Sultan Against His People", BS. Isaac, \& I. Lasker, Editors, 1962, (çevrimiçi) http:// www. marxists.org/archive/lenin/ works/1905/jul/10bs.htm, 15 Ocak 2012.

Matushenko, A, "The Revolt on the Armoured Cruiser "Potemkin", (çevrimiçi) http://www. marxist.com/ History-old/ potemkin.html, 28 Şubat 2011.

Miller, A. F., "Burjuaznaya Revolyuçiya 1908 g. v Turçii", Sovetskoe Vostokvedenie, (6), 1955.

, "Mladotureçkaya Revolyuçiya", Pervaya Russkaya Revolyuçiya 1905-1907 gg. i Mejdunarodnoe Revolyuçionnoe Dvijenie, c. 2, Moskova, Akademiya Nauk SSSR Otdelenie İstoriçeskih Nauk, 1956.

Reisner, İ. M., "Russkaya Revolyutçiya 1905-1907 gg. i Probujdenie Azii", Sovetskoe Vostokvedenie, (2), 1955.

"Russia and Turkey", Marlborough Express, 21 November 1905.

"Russia and Turkey, Fortifications on the Bosphorus", Taraniki Herald, 19 September 1905.

"Russia and Turkey", Wangauni Herald, 20 July 1905.

Sale, Jonathan, “Potemkin Mutiny, 27 June 1905”, New Statesman, Sale, 21 June 1996.

Sayg1l, Hasip, "The Condolence Message of the Ottoman Black Sea Fleet in 1906: Critique of a Russian Red Archive Document", Gazi Akademik Bakış, Kış 2012.

“Sergei Eisenstein”, The History Teacher, 29/4, August 1966. 
Şpilkova, V. İ., Mladotureçkaya Revolyuçsiya 1908-1909 gg., Moskova, İzdatelstvo "Nauka" Glavnaya Redakçiya Vostoçnoi Literaturi, 1977.

Tahsin Paşa, Abdülhamit ve Yıldız Hatıraları, İstanbul, Muallim Ahmet Halit Kitaphanesi, 1931.

Taranaki Herald, 20 July 1905.

“The Odessa Mutiny- Turkish Precautions", The Times, 4 July 1905.

"The Potemkin Leaves Constanza", The Times, 4 July 1905.

“Turkey's New Move”, Ashburton Guardian, 10 July 1905.

Spector, Ivar, The First Russian Revolution-Its Impact on Asia, New Jersey, Printice-Hall Inc, 1962. Spector, 1962.

Weinberg, Robert, "Workers, Pogroms, and the 1905 Revolution in Odessa", The Russian Review, 46, 1987.

Wood, Alan, The Origins of the Russian Revolution 1861-1917, 3 ed., Routledge, 2003.

Yeykeles, İgor, Potemkin Mutiny, In J. R. Miller, Encyclopedia of Russian History, New York, Macmillan Reference USA, 2004.

Zebroski, Robert, "The Battleship Potemkin and its Discontents, 1905-An International Perspective", Naval Mutinies of the Twentieth Century, by C. M. Bell and Bruce A. Elleman, Cornwall United Kingdom, Frank Cass Publishers, 2003. 